\title{
SOSIALISASI LEGALITAS DAN MANAJEMEN PEMASARAN BAGI UMK (LEGALITY SOCIALIZATION AND MARKETING MANAGEMENT FOR MSE's)
}

\author{
Ades Rajayana $^{1)}$, Sri Yuni Widowati ${ }^{2)}$, Emaya Kurniawati ${ }^{3)}$, Aprih Santoso ${ }^{\left.4)^{*}\right)}$ \\ 1)23)4) Fakultas Ekonomi Universitas Semarang \\ ${ }^{*}$ Penulis Koresponden, email : aprihsantoso@usm.ac.id
}

\begin{abstract}
ABSTRAK
UMK di Kecamatan Cepiring Kabupaten Kendal memiliki usaha dalam rangka peningkatan pendapatan keluarga salah satu usahanya adalah membuat atau memproduksi makanan ringan dan minuman kesehatan yang selama ini pemasarannya masih dilingkup kerabat dekat atau keluarga. Permasalahn yang dihadapi oleh pelaku usaha khususnya UMK di Kecamatan Cepiring Kabupaten Kendal adalah belum memiliki merk atau nama bagi hasil produknya dikarenekan terbatasnya pengetahuan tentang merk dan belum mengetahui bagaiman caranya untuk mendapatkan merk dagang bagi produknya. Pelaksanaan sosialisasi merk dan manajemen usaha akan menghasilkan informasi tentang pentingnya merk dan cara untuk mendaftarkan merk dagang bagi produk yang dihasilkan oleh UMK sehingga bermanfaat untuk pendukung kinerja UMK di Kecamatan Cepiring Kabupaten Kendal.
\end{abstract}

Kata kunci: Merk, Manajemen, Pemasaran

\section{ABSTRACT}

MSE's in Cepiring District Kendal Regency have a business in order to increase family income. One of the efforts is to make or produce snacks and health drinks, which have so far been covered by close relatives or families. The problem faced by businesses, especially MSE's in Cepiring District, Kendal Regency, is that they do not have a brand or product name due to the limited knowledge of the brand and do not know how to get a trademark for their products. The problem faced by businesses, especially MSE's in Cepiring District, Kendal Regency, is that they do not have a brand or product name due to the limited knowledge of the brand and do not know how to get a trademark for their products. The implementation of brand socialization and business management will produce information about the importance of brands and ways to register trademarks for products produced by MSEs so that it is useful for supporting MSE performance in Cepiring District, Kendal Regency.

Keywords: Brand, Management, Marketing

\section{PENDAHULUAN}

Usaha Mikro Kecil (UMK) keseluruhan di Kecamatan Cepiring Kabupaten Kendal berjumlah 35 usaha. dengan berbagai usaha yaitu produk Makanan Ringan yaitu kue-kue basah maupun kue kering dan minuman kesehatan yang terbuat dari bahan bahan tradisional seperti Temu Lawak, Kunyit Asem, Jahe. Dalam menghasilkan berbagai jenis produk selama ini kemasan yang dipakai untuk membungkus produk tidak tercantum merk atau nama produksinya, sehingga belum dikenal oleh masyarakat dan tidak bisa membedakan dengan produk sejenis lainnya yang juga tidak memliki nama atau merk.

Selanjutnya, pelaku usaha juga perlu diberikan penyuluhan mengenai pentingnya pemberian merek pada produk barang/jasa yang dimiliki, karena selain sebagai tanda pembeda, merk juga memiliki fungsi penting sebagai hak 
kepemilikan agar merek yang dimiliki terhindar dari penjiplakan/peniruan oleh pelaku usaha lain. Fungsi inilah yang belum diketahui oleh pelaku usaha sebagai legalitas merk, karena berdasarkan pemahaman pelaku usaha merk hanya sekedar tanda pembeda saja. Pemberian merek atau branding merupakan hal yang sangat penting bagi badan usaha tertentu/perusahaan karena merk dapat membedakan produk yang satu dengan yang lain. Merek dapat menjadi nilai tambah bagi produk baik bagi produk barang maupun jasa..

Karena belum memiliki nama atau merk maka hasil produksi dan yang dihasilkan oleh UMK Kecamatan Cepiring Kabupaten Kendal pemasarannya masih didalam lingkup sekitarnya dengan hasil penjualan sangat terbatas pada kerabat dekat maupun keluarga sendiri.
Pengabdian kepada masyarakat yang dilaksanakan berfokus pada pelaku usaha UMK di Kecamatan Cepiring sebagai target program dengan tujuan agar pelaku usaha UMK mendapatkan pemahaman mengenai legalitas (merk) dan manajemen usaha (manajemen pemasaran) sehingga pemahaman tersebut dapat diterapkan dalam kegiatan usaha serta dapat memperbaiki kualitas usaha yang sedang dijalankan. Salah satu tolok ukur berkembangnya usaha adalah adanya legalitas (merk) dan manajemen pemasaran sehingga dapat peningkatan omset.

Usaha Mikro Kecil (UMK) di Kecamatan Cepiring Kabupaten Kendal. dengan berbagai usaha yaitu produk Makanan Ringan minuman kesehatan menghadapi masalah usaha, yaitu :

Tabel 1. Masalah yang Dihadapi

\begin{tabular}{|l|}
\hline \multicolumn{1}{|c|}{ Aspek Legalitas Usaha } \\
\hline UMK Kecamatan Cepiring kabupaten Kendal \\
yang sudah menghasilkan produk makanan \\
ringan dan minuman kesehatan masih belum \\
mengerti tentang nama atau merk produksi \\
\hline $\begin{array}{l}\text { Pelaku usaha belum memiliki merk dagang/jasa } \\
\text { serta belum mengetahui fungsi merk dalam } \\
\text { kegiatan usaha }\end{array}$ \\
\hline $\begin{array}{l}\text { Belum adanya pemahaman mengenai legalitas } \\
\text { usaha khususnya legalitas merk, sehingga } \\
\text { merk yang dimiliki pelaku usaha UMK rentan } \\
\text { dijiplak/ditiru oleh pihak lain }\end{array}$ \\
\hline
\end{tabular}

Tujuan PKM ini adalah memberikan sosialisasi sosialisasi legalitas dan manajemen usaha pada UMK di Kecamatan Cepiring Kabupaten Kendal.

\section{METODE PELAKSANAAN KEGIATAN}

Masih kesulitan tersendiri bagi UMK dalam mempulikasikan dan mempromosikan hasil produksi usahanya

Belum adanya pemahaman manajemen usaha khususnya mengenai strategi pemasaran sehingga pelaku usaha belum dapat mengembangkan usahanya secara optimal

berdasarkan tabel 2: Didalam melakukan kegiatan PKM ini Tim PKM menggunakan metode penyuluhan kepada UMK di Kecamatan Cepiring melalui pemaparan, diskusi dan praktek kasus.

Tahapan kegiatan program dapat dilihat 
Tabel 2. Tahapan Kegiatan Program PKM

\begin{tabular}{|l|l|}
\hline \multicolumn{2}{|c|}{ Tahap Persiapan } \\
\hline Pra-Survei & $\begin{array}{l}\text { Identifikasi permasalahan dan kebutuhan UMK (permasalahan } \\
\text { spesifik yang dialami mitra) }\end{array}$ \\
\hline Pembentukan Tim PKM & $\begin{array}{l}\text { Pembentukan Tim disesuaikan dengan jenis kepakaran untuk } \\
\text { menyelesaikan permasalahan UMK }\end{array}$ \\
\hline Pembuatan Proposal & $\begin{array}{l}\text { Pembuatan proposal untuk menawarkan solusi permasalahan dan } \\
\text { penyediaan dana dalam pelaksanaan solusi bagi UMK }\end{array}$ \\
\hline Koordiasi Tim \& Mitra & $\begin{array}{l}\text { Perencanaan pelaksanaan program secara konseptual, operasional dan } \\
\text { job describtion dari Tim dan UMK }\end{array}$ \\
\hline $\begin{array}{l}\text { Persiapan Alat \&Bahan } \\
\text { Pelatihan }\end{array}$ & Pembelian dan penyewaan alat serta pembuatan materi kegiatan \\
\hline \multicolumn{2}{|c|}{ Tahap Pelaksanaan } \\
(Kegiatan Dilaksanakan di Lokasi UMK)
\end{tabular}

Ada beberapa metode pendekatan yang digunakan dalam pelaksanaan PKM, meliputi :

\section{Sosialisasi}

Program pengabdian kepada masyarakat dilaksanakan dalam bentuk sosialisasi kepada pelaku usaha UMK di Kecamatan Cepiring Kabupaten Kendal. Sosialisasi tersebut berupa pemaparan materi terkait permasalahan yang dihadapi yaitu aspek hukum tentang pentingnya merk dan aspek manajemen. Pemberian merk atau branding merupakan hal yang sangat penting bagi badan usaha tertentu/ perusahaan. Karena merk dapat membedakan produk yang satu dengan yang lain. Materi yang akan disampaikan diharapkan dapat memberikan peningkatan pengetahuan dan pemahaman untuk selanjutnya dapat diterapkan oleh UMK dalam kegiatan usaha. Adapun materi yang akan disampaikan pada UMK meliputi : 
Tabel 3. Materi Program PKM

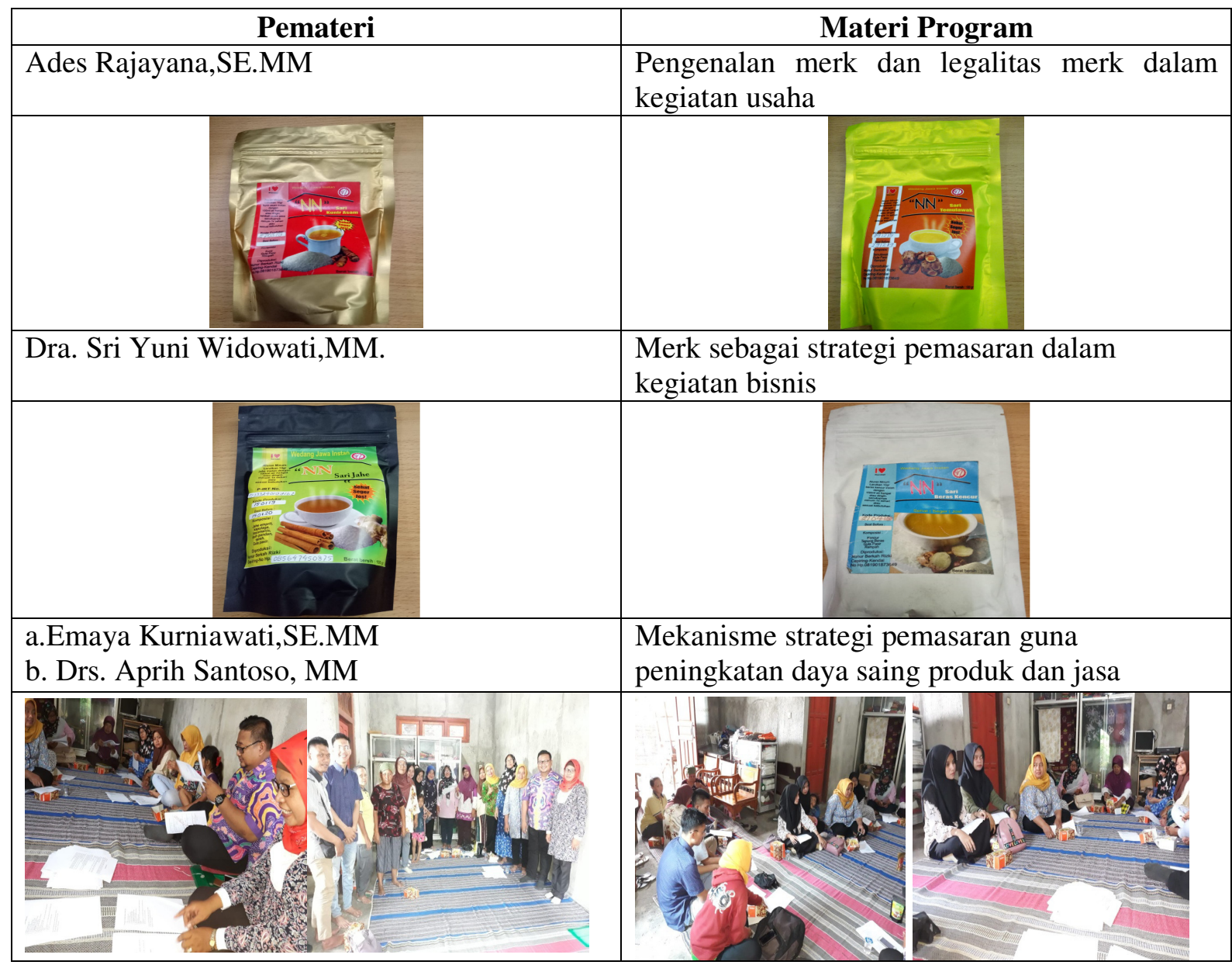

\section{Diskusi}

Setelah materi selesai dipaparkan, dilanjutkan dengan diskusi berupa tanya jawab antara pemateri dengan peserta. Diskusi dilakukan agar peserta lebih memahami materi yang telah disampaikan. Melalui diskusi, sosialisasi tidak hanya sekedar transfer knowledge saja melainkan dapat sharing pengalaman maupun permasalahan yang sedang dihadapi oleh peserta pengabdian

\section{Evaluasi Program}

\section{(1) Evaluasi Awal}

Kegiatan tahap ini untuk mengevaluasi kegiatan usaha yang telah dilakukan saat ini dan penyelesaian permasalahan yang dijadikan prioritas.

\section{(2) Sosialisasi}

Kegiatan tahap ini bertujuan untuk meningkatkan ketrampilan sumber daya manusia dari UMK di Kecamatan Cepiring Kabupaten Kendal. Kegiatan ini dilaksanakan dengan memberikan pengetahuan tentang arti pentingnya merk bagi suatu produk dan bagaimana caranya untuk mendapatkan merk dagang dengan resmi bagi hasil produksi serta memberikan penjelasan tentang pentingnya pemasaran bagi produk yang sudah dihasilkan sehingga dapat meningkatkan omzet penjualan yang akan berpengaruh terhadap naiknya keuntungan. Dengan cara ini diharapkan dapat 
lebih intensif dalam menerima materi yang diberikan dan diharapkan mampu mengembangkan usaha.

\section{HASIL DAN PEMBAHASAN}

\section{Proses Pelaksanaan Kegiatan}

Dalam Pelaksanaan PKM diharapkan pelaksanaannya dapat memanfaatkan waktu pelaksanaan dengan efisien dan efektif sehingga hasil yang diharapkan dapat tecapai. Tahaptahap dalam pelaksanaan kegiatan PKM sebagai berikut:

1. Melakukan survei lokasi yang menjadi obyek pengabdian yaitu UMK Kecamatan Cepiring Kabupaten Kendal dan melakukan wawancara awal tentang pelaksanaan kegiatan PKM yang alan dilaksanakan

2. Membagikan undangan kepada pelaku UMK di Kecamatan Cepiring Kabupaten Kendal supaya hadir dalam pelaksanaan penyuluhan dan pengabdian masyarakat.

3. Pelaksanaan PKM dilaksanakan pada hari Kamis, 24 Januari 2019.

\section{Hasil Evaluasi Pengabdian Kepada Masyarakat}

Kegiatan Pengabdian tentang Sosialisasi Legalitas dan Manajemen Pemasaran bagi Pelaku Usahs UMK di Kecamatan Cepiring Kabupaten Kendal memberikan sosialisasi bagaimana pentingnya sebuah merk untuk suatu produk sehingga lebih dikenal oleh konsumen selain itu juga bisa membedakan antara produk yang dihasilkan seseorang dengan beberapa produk orang yang lain. tanya jawab dari materi yang sudah disampaikan khususnya bagaimana membuat merk untuk suatu hasil produksi dan bagaimana cara mendaftarakan suatu produk untuk mendapatkan merk secara legal.

\section{Hasil Evaluasi Faktor Pendorong :}

Faktor-faktor yang mendorong UMK di Kecamatan Cepiring Kabupaten Kendal adalah :

1. Para peserta ingin produk yang dihasilkan mempunyai merk sehingga memudahkan pembeli untuk mengenalnya.

2. Para peserta ingin produknya mendapatkan hasil produksinya terpasarkan lebih luas lagi.

\section{KESIMPULAN}

Pelaksanaan PKM tentang Sosialisasi Legalitas dan Manajemen Usaha bagi pelaku usaha UMK di Kecamatan Cepiring Kabupaten Kendal dapat membantu pelaku usaha dalam meningkatan pengetahuannya tentang arti pentingnya merk yang akan membedakan hasil produknya dengan produk sejenis lainnya serta lebih dikenal di pasaran. Dalam sosialisasi pelaku usaha dapat pula mengetahui fungsi manajemen pemaaran dan strategi apa saja yang harus dipenuhi dalam memasarkan produk dengan merk yang akan didaftarkannya.

\section{SARAN}

Saran bagi Kegiatan Pengabdian Masyarakat ini yaitu dapat dilangsungkan di UMK lain di linguungan Kabupaten Kendal, dan dapat dilakukan pengabdian lebih lanjut dengan materi yang lebih luas lagi sehingga sangat bermanfaat bagi UMK dalam mengembangkan usahanya.

\section{UCAPAN TERIMA KASIH}

Tim PKM Fakukltas Ekonomi Universitas Semarang (USM) menghaturkan banyak terima kasih kepada UMK di Kecamatan Cepiring 
Kabupaten Kendal yang sudah berpartisipasi sebagai peserta dan bekerjasama untuk melakukan kegiatan pengabdian kepada masyarakat yang berupa Sosialisasi Legalitas dan Manajemen Usaha bagi pelaku usaha.

Tidak terkecuali, Tim PKM Fakukltas Ekonomi Universitas Semarang (USM) juga menghaturkan banyak terima kasih kepada seluruh Pengelola Jurnal 'LOGISTA" Departement of Agricultural Product Technology, Faculty of Agricultural Technology, Universitas Andalas, atas kerjasamanya dalam penerbitan artikel ini.

\section{REFERENSI}

Anonim. Keputusan Dirktur Jenderal Kekayaan Intelektual No. HKI-02.HI.06.01 Tahun 2017 tentang Formulir Permohonan Merk

BPS, 2018. Kendal Dalam Angka

Hasibuan. 2011. Manajemen, Dasar, Pengertian dan Masalah. Jakarta : Bumi Aksara

Sari, E.K, dkk, 2008. Hukum dalam Ekonomi. Jakarta : PT Gramedia Widiasarana Indonesia

Sutrisno, Joko dan Sri Lestari, 2006. Kajian Usaha Mikro Indonesia. Jurnal Pengkajian Koperasi dan UKM Nomor 2 Tahun I-2006

Undang-Undang Republik Indonesia Nomor 20 Tahun 2008 tentang Usaha Mikro, Kecil dan Menengah 